\title{
COVID-19: A dreaded pandemic
}

\author{
Tanuja P. Manohar ${ }^{1^{*}}$, Ramesh P Mundle ${ }^{2}$ \\ ${ }^{1}$ Professor, Dept. of Medicine, N. K. P. Salve Institute of Medical Sciences \& Research Centre and Lata Mangeshkar Hospital, Digdoh \\ Hills, Hingna Road, Nagpur, Maharashtra, India \\ *Corresponding Author: Tanuja P. Manohar \\ Email: tanuja.manohar9@gmail.com
}

What started as an unusual respiratory tract infection in Wuhan, China in December $2019^{1}$, has spread it's roots across the globe, in all continents except Antarctica. Controversy related to origin of this virus is still remained unanswered. Because of it's resemblance to SARS virus, this new virus was labeled as Severe acute respiratory syndrome-Corona virus $2\left(\mathrm{SARS}-\mathrm{CoV}_{2}\right)^{2}$ and disease caused by SARS-CoV 2 is referred to as COVID-19. ${ }^{3}$ Disease predominantly spreads by respiratory droplets, directly or through fomites. ${ }^{4}$ Clinical spectrum of COVID-19 varies from asymptomatic or mild to severe life threatening cases. Incubation period is 2-14 days. Fever,cough and shortness of breath being commonest symptoms, fatigue, shaking chills and loss of sense of smell and taste are also commonly found symptoms. Almost $81 \%$ patients have mild symptoms while $14 \%$ need admission to hospital and only $5 \%$ become critical and require ICU care. ${ }^{5}$ Older people, and people with pre-existing medical conditions (such as asthma, diabetes, heart disease) appear to be more vulnerable to becoming severely ill with the virus. $^{5}$

Diagnosis is based on detection of viral antigen in respiratory secretion by Reverse-Transcriptase Polymerase chain reaction (RT-PCR). ${ }^{6}$ We are adopting guideline laid by ICMR for testing the samples. WHO has advised measures like aggressive case finding, test all suspect cases, and test all of their contacts who develop symptoms. Amongst all states Kerala adopted these measures meticulously and to great extent able to contain spread of virus. Many experts from our own country and also globally criticized India for testing less number of samples and thereby projecting less number of cases than actual. However resource limited country like India, possibly this is the best policy.

WHO declared COVID-19 as pandemic on $12^{\text {th }}$ March 2020. Government of India took many proactive steps right from beginning of pandemic even before first case was detected in India. Measures like screening of incoming air passengers, followed by suspension of visas and a ban on international flights were done much ahead of any other country. Thermal screening of incoming international passengers from China and Hong Kong was started on $18^{\text {th }}$ January. In India first case of COVID-19 was detected on $30^{\text {th }}$ January in a person who was returned from Wuhan, China. India started taking social distancing measures like closing workplaces and schools before reaching 100 confirmed cases. Social awareness related to importance of hand wash, social distancing was also started simultaneously. When India was struggling to reduce spread of virus by all means, an important major lapse occured as a result of a religious gathering at Delhi. From then onwards cases started increasing all across the country. On $25^{\text {th }}$ March nationwide lock down was imposed on India, initially for 3 weeks and was extended further twice in majority of states. This was necessary step taking into consideration, population density, proportion of patient below poverty line and less developed public health-care system especially in rural India. Whatever may be the reason, like immunity of Indian people, less virulent strain of virus, climatic condition or proactive government initiatives, so far India is able contain disease as compared to western world, where there is robust health care system, more aggressive testing strategy and better literacy level. According to some experts, a lockdown might delay severe cases for a while, but once restrictions are eased, cases will reappear. $^{7}$

The key health care challenge of the COVID-19 pandemic is the safe delivery of respiratory support on a large scale. Post lock down, there can be surge or steep rise in number of COVID-19 cases. Ultimately it is predicted by experts in the field that major population will get infected at the end of an year or so ${ }^{7}$. Because of lockdown Indian authorities got time to prepare ourselves to face this dreaded pandemic. Government is trying to strengthen our health care system by training doctors, developing infrastructure and revitalizing already existing health schemes. Also during this period scientists across the globe may get at-least some direction towards development of new drug or vaccine.

As countries around the world are preparing for reopening of their economies and a gradual return to normal life, we in India should also start thinking in those lines about new post-COVID era. There is no doubt that COVID-19 is going to dictate every aspect of our lives in almost every corner of the country. Also there will be huge effect on various industries especially hospitality, entertainment, airlines, shopping malls etc. Drastic changes are also expected to occur in funding for health-sector, which has remained neglected so far in India. The COVID19 pandemic crisis is a true eyeopener reminding the Governments across the globe about importance of investing in healthcare sector.

\section{Conflict of Interest}

None. 


\section{Source of Funding}

None.

\section{References}

1. World Health Organization. Pneumonia of unknown causeChina. Emergencies, preparedness, response, disease outbreak news, World health organization (WHO) 2020 Jan. disease outbreak news, 5 January.

2. Coronaviridae study group of the international committee on taxonomy of viruses. The species severe acute respiratory syndrome-related corona virus: classifying $2019-\mathrm{nCoV}$ and naming it SARS-CoV-2. Nat Microbiol. 2020;5(4),536-44. https://doi.org/10.1038/s41564-020-0695-z.

3. WHO Director-General's remarks at the media briefing on 2019-nCoV on 11 February 2020. Available on: https://www.who.int/dg/

speeches/detail/who-director-general-s-remarks-at-themediabriefing-on-2019-ncov-on-11-february-2020.
4. Modes of transmission of virus causing COVID-19: Implications for IPC precaution recommendations. Scientific Brief 29 March 2020

WHO/2019-nCoV/Sci_Brief/Transmission_modes/2020.

5. Pauline V, Lan VD, L'Huillier A G, Manuel S, Laurent K, Frederique J. Clinical features of covid-19. BMJ. 2020;369:m1470.

6. Tang YW, Schmitz JE, Persing DH, Stratton CW. The Laboratory Diagnosis of COVID-19 Infection: Current Issues and Challenges. J Clin Microbiol. 2020. doi:10.1128/JCM.00512-20.

7. Giesecke J. The invisible pandemic. www.thelancet.com, 2020. https://doi.org/10.1016/S0140-6736(20)31035-7

How to cite: Manohar TP, Mundle RP. COVID-19: A dreaded pandemic. Panacea J Med Sci. 2020;10:1-2. 